\title{
Use of Demolished Concrete Waste for Resurfacing of Low Volume Roads in Sri Lanka Using Roller Compacted Concrete (RCC) Technology
}

\author{
W.R.A.N. Jayantha and W.K. Mampearachchi
}

\begin{abstract}
Roller Compacted Concrete Pavement (RCCP) is a type of zero-slump concrete product, which has renewed the interests of designers of sustainable pavements with its potential to reduce the cement content of the concrete mixture. RCC is produced with the same ingredients as in conventional concrete but with different blend proportions. RCCP construction procedure is similar to that of asphalt paving, where laying is performed using a modified asphalt paver, and steel drum rollers follow the paver to ensure the laid RCC mixture to be compacted to its desired density.

This research aims to evaluate the applicability of deteriorated concrete pavement to reconstruct new pavement in an economical and sustainable approach. In this study, manually crushed concrete slabs were washed, sieved, and tested for aggregate strength to be used as a substitution for coarse aggregates (CA) in RCC. The soil compaction method is used for mix design, and the Vibratory Hammer Test (VHT) is used in place of the Modified Proctor Test (MPT) in determining the optimum moisture content (OMC) of RCC. The importance of incorporating the VHT in the mixture design process and the possibility of complete replacement of CA of RCC by Recycled Concrete Aggregate (RCA) are elaborated in this research.
\end{abstract}

Keywords: Roller Compacted Concrete, Optimum Moisture Content, Vibratory Hammer, Soil Compaction Method

\section{Introduction}

Sri Lanka has a spread-out road network of $116,000 \mathrm{~km}$ in total and is classified into National, Provincial, Pradeshiya Sabha, and Local Authority roads based on administrative responsibility and functionality [1]. 12,496km of National Highways (" $A$," " $B$," and "E" class roads, July 2020 update) are constructed mainly using asphalt paving techniques [2]. Even though the national road network contains a limited number of concrete pavements, Pradeshiya Sabha and Local Authority roads have a considerable length of concrete roads. Since 2007, concrete paving has been widely used to construct low volume roads in Sri Lanka. Even though concrete pavements are durable in the norm, owing to poor construction practices and improper maintenance, the concrete surfacing of low volume roads is vulnerable to frequent damages [3]. As a result, these pavements require further attention to rehabilitation by relevant authorities more often. However, the current practices for the repair of these severely damaged concrete roads are either obliterating the pavement slab or using the demolished pavement slab as a base layer to the new surfacing. Therefore, rather than using the old pavement slab as a base for the new pavement, the pavement slab can be recycled to extract aggregates and make RCC using the RCA obtained from the recycled pavement. The challenges faced during this process and the possible optimizations are expected to be revealed scientifically in this paper.

\section{Roller Compacted Concrete (RCC)}

As implied by the name, the compaction of RCC into its final form is achieved by heavy vibratory steel drum and rubber-tired rollers. Since RCC is a type of non-reinforced concrete, high-density pavers can be used for placing concrete. RCC has similar strength properties and consists of the same basic ingredients as

Eng. W. R. A. N. Jayantha, AMIE (SL), B.Sc. Eng. Hons (Moratuwa), Graduate Research Assistant, Department of

Civil Engineering, University of Moratuwa,

Email: jayanthawran.20@uom.lk

https://orcid.org/0000-0003-1657-6592

Eng. (Prof.) W. K. Mampearachchi, CEng, MIE (SL),

B.Sc. Eng. (Hons), MSCE (South Florida), Ph.D. (Florida),

CMILT UK, Senior Lecturer, Department of Civil

Engineering, University of Moratuwa,

Email:wasanthak@uom.lk

iD https://orcid.org/0000-0002-8762-1234 
conventional concrete: well-graded aggregates, cementitious materials, and water but with different blend of ingredients [4].

The most significant difference between RCC mixtures and conventional concrete mixtures is that RCC has a higher percentage of fine aggregates, which allows for tight packing and consolidation [5], [6]. As pointed out by the U.S. Army Corps of Engineers (USACE) in 1995, RCC has made savings ranging from 14 to 58 percent. This comparative study analyzes 49 different USACE projects [7], [8].

Table 1 - A Typical Comparison between Conventional Concrete and RCC Pavements Mix Design [9], [10]

\begin{tabular}{|c|c|c|}
\hline Pavement type & $\begin{array}{c}\text { Roller } \\
\text { Compacted } \\
\text { Concrete }\end{array}$ & $\begin{array}{l}\text { Conventional } \\
\text { Concrete }\end{array}$ \\
\hline $\begin{array}{ll}\text { Max. } & \text { Aggregate } \\
\text { Size } & \\
\end{array}$ & $19 \mathrm{~mm}$ & $38 \mathrm{~mm}$ \\
\hline Water & 105 & 140 \\
\hline 若 Cement & 260 & 329 \\
\hline $\begin{array}{lll} & 0 & \text { Fine } \\
3 & 000 & \text { Aggregate }\end{array}$ & 946 & 606 \\
\hline \begin{tabular}{|l|l} 
& $\begin{array}{l}\text { Coarse } \\
\text { Aggregate }\end{array}$ \\
\end{tabular} & 1254 & 1356 \\
\hline $\begin{array}{l}\text { Water } \quad \text { Content } \\
(\%)\end{array}$ & 5.4 & 7.8 \\
\hline
\end{tabular}

Intensive usage of natural resources in construction activities will cause negative impacts on the environment. The cement industry is responsible for $5 \%$ of global anthropogenic carbon dioxide emissions. For every $1000 \mathrm{~kg}$ of cement produced, nearly 900 $\mathrm{kg}$ of $\mathrm{CO}_{2}$ will be disposed of to the environment. [11]. However, the advancements in cement production have decreased the amount of $\mathrm{CO}_{2}$ emission in the recent past [12]. RCC can further reduce the percentage of cement used in pavement applications and the energy required for transportation [13]. A typical RCC mix proportion is compared with a conventional concrete mix proportion in Table 1.

When compared to conventional concrete, RCC placed with new high-density pavers offers many technical and economic advantages. It is possible to achieve high quality in terms of strength, durability, and surface finish at the relatively low device and labour costs. Table 2 shows a comparison of the properties of RCC and conventional concrete.

\subsection{Construction Method}

The construction method of RCC is similar to that of asphalt laying, and the following steps are followed during the construction sequence [14], [15].

1) Subgrade, Subbase, and Base Course Preparation:

The subgrade should be uniformly compacted to a minimum of $95 \%$ of the maximum dry density and sub-base, and the base course also is prepared according to fundamental practices.

2) Transporting RCC:

Dump trucks are used to transport RCC, and relevant preventive measures should be taken to avoid segregation and moisture loss.

Table 2 - Comparison of Properties of RCC vs Conventional Concrete [16]

\begin{tabular}{|l|l|l|}
\hline Property / Task & Roller Compacted Concrete & Conventional Concrete \\
\hline Aggregate Gradation & $\begin{array}{l}\text { Well graded aggregates are used } \\
\text { to minimize air voids }\end{array}$ & $\begin{array}{l}\text { Less graded when compared to } \\
\text { RCC }\end{array}$ \\
\hline Cementitious Material Content & $\begin{array}{l}\text { For pavement applications, } \\
\text { cement content is decided on the } \\
\text { basis of the percentage of weight. } \\
\text { of the mix and the desired } \\
\text { compressive strength }\end{array}$ \\
\hline Moisture Content & $\begin{array}{l}\text { Optimum moisture content } \\
\text { OMC) is used as the moisture } \\
\text { content of the mix }\end{array}$ & $\begin{array}{l}\text { Determined based on the w/c } \\
\text { ratio mix }\end{array}$ \\
\hline Concrete Mixing & Pugmills or Mixers & Mixers \\
\hline Transportation & Dump Trucks & $\begin{array}{l}\text { Manually/Slipform } \\
\text { machines }\end{array}$ \\
\hline Laying & High-density paving machines \\
\hline Compaction & Steel drum rollers & Vibratory machines \\
\hline Strength & High (For constant cement & $\begin{array}{l}\text { Lower than RCC (For constant } \\
\text { cement content) }\end{array}$ \\
\hline Permeability & Relatively high & Relatively less \\
\hline
\end{tabular}


3) Trial Construction (Test Strips):

This is performed mainly to verify whether the design requirements are met.

4) Placement:

Placement should be carefully done using a paver, and the steel drum rollers should compact the mix at the same time with the recommended number of roller-passes.

5) Curing:

White concrete curing compound can be used conforming to ASTM C309.

Construction methodology will be faster than the usual practice, and the release of the pavement to traffic will depend on the strength gain of RCC. Typically, in warm climatic conditions, pavement can be released to traffic after two days since construction [5], [15].

\subsection{Mix Design of RCCP}

The four main proportioning methods are the soil compaction test, concrete consistency test, solid suspension model, and the optimal paste volume method. The soil compaction method is the most used technique for RCC pavements [17]-[19].

In this study, the soil compaction method is used for RCC mix design as in ACI 211.3R-12 Guide for Selecting Proportions for No-Slump Concrete by ACI Committee 211 [20]. The mix design steps of the soil compaction method can be listed as,
2) Calculating Mix Proportions:

3) Calculating Mix Proportions:

Aggregates were sieved and prepared to meet Roller Compacted Concrete Pavement (RCCP) gradation. Figure 1 shows the gradation bands used for the mix design. Coarse aggregates are defined as passing $19 \mathrm{~mm}$ and retained on $4.75 \mathrm{~mm}$ passing $4.75 \mathrm{~mm}$ sieve sizes. Sieves of $25 \mathrm{~mm}, 19 \mathrm{~mm}$, $12.7 \mathrm{~mm}, 9.5 \mathrm{~mm}, 4.75 \mathrm{~mm}, 1.18 \mathrm{~mm}, 0.15 \mathrm{~mm}$, and $0.075 \mathrm{~mm}$ were used for aggregate gradation.

4) Selecting Cementitious Content:

Determination of the cementitious content is required to optimize the mix design. The available literature and previous RCC projects clearly show that the cementitious content lies typically between $11-13 \%$ by weight of dry materials in the mixture. Therefore, the fixed cement content of $12 \%$ was used for casting RCC samples.

5) Moisture-Density Plot (Proctor compaction test ASTM D1557) and selection of optimum moisture content:

To determine the optimum moisture content (OMC) for the mix, the standard specifies to use the Modified Proctor Compaction Test (ASTM D1557). To simulate the actual site condition of compaction, a compaction test was carried out by a Vibratory Hammer (BS1377: Part 4: 1990) in this study to compare it with the Modified Proctor Test.

1) Aggregate Gradation:
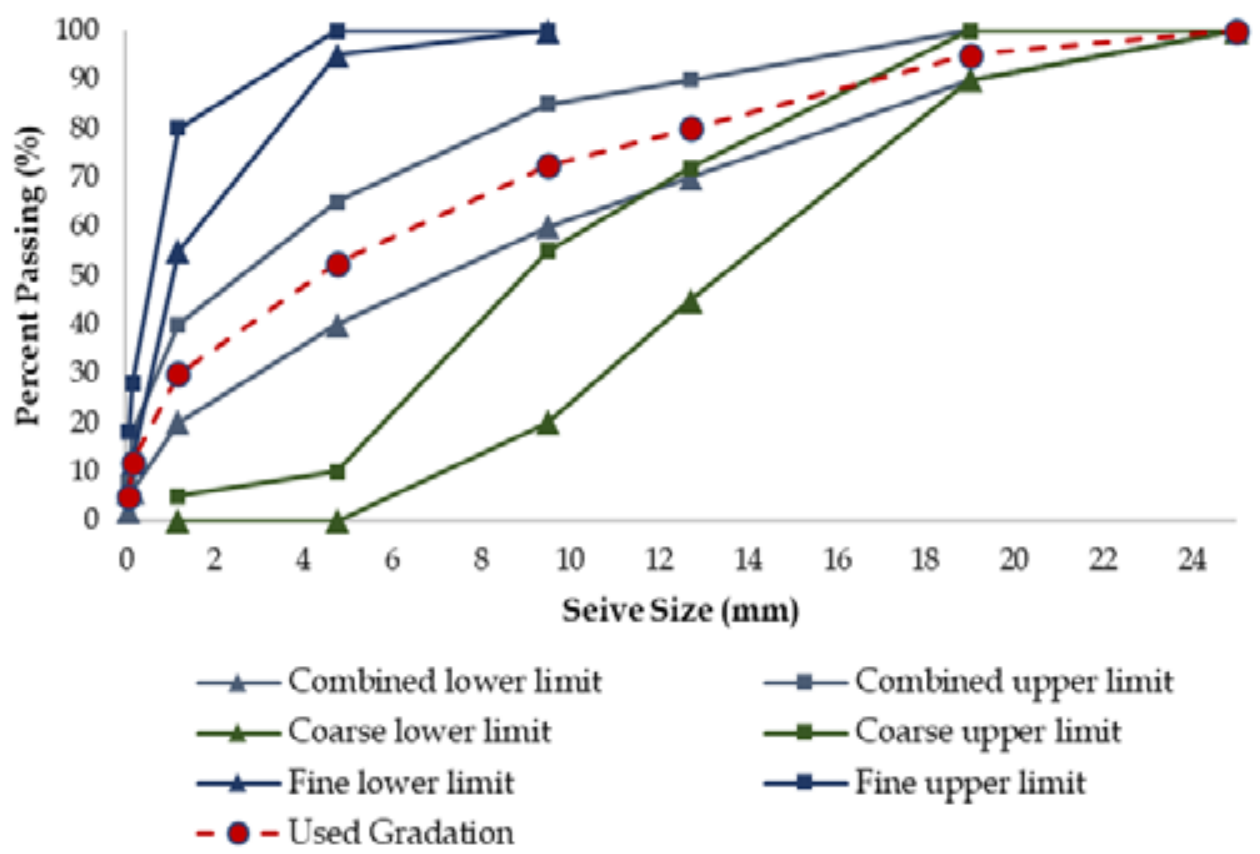

Figure 1 - RCCP Gradation Bands 
Since the cementitious material content of the mix is $12 \%$ of the total dry mass,

$$
W_{d}\left(W_{c}+W_{a}\right)=0.12
$$

After establishing the OMC,

$$
W_{u} /\left(W_{c}+W_{a}\right)=(O M C) / 100
$$

For $1 \mathrm{~m}^{3}$ of RCC mix, assuming $1.5 \%$ of air voids,

$$
W_{a}\left(1 / S G_{a}-A\right)+W_{d} / S G_{c}+W_{w} / S G_{w}=985
$$

Where,

$$
\begin{array}{ll}
W_{c} & =\text { Dry Weight of cement } \\
W_{a} & =\text { Dry Weight of aggregates } \\
W_{w} & =\text { Weight of water } \\
S G_{c} & =\text { Specific Gravity of cement } \\
S G_{a} & =\text { Specific Gravity of aggregates } \\
S G_{w} & =\text { Specific Gravity of water } \\
A & =\text { Water absorption of aggregate } \\
& \text { mix }
\end{array}
$$

The mixing ratio of coarse and fine aggregates was as follows,

$$
\begin{aligned}
& \text { Coarse }=53.33 \% \text { of total aggregates } \\
& \text { Fine }=46.67 \% \text { of total aggregates }
\end{aligned}
$$

6) Compressive Strength Test:

After determining the mix proportions, RCC was mixed and cast into cylindrical moulds of $152.4 \mathrm{~mm}$ diameter and $300 \mathrm{~mm}$ height. The vibration was applied by a vibratory hammer, and the concrete was compacted in four layers. When a mortar ring appeared around the tamping plate, the vibration was stopped. ASTM C1435 describes the method of moulding RCC into cylindrical moulds in detail.

\subsection{RCC made with Recycled Concrete Aggregates (RCA)}

Recycled aggregates are different from natural aggregates due to the presence of cement gangue of old mortar, which remains attached to the natural aggregates after crushing of the original concrete and induces lower densities and greater capacity of water absorption [21].

A polished cylindrical specimen prepared only using coarse RCA and white cement is shown in Figure 2. The white spaces in the left photo are new white mortar, and the darker spots are the virgin aggregates in RCA. Virgin aggregates of RCA are already bounded by the old mortar, and this results in weaker aggregate properties [22].

RCC consisting of only crushed concrete is comparable in compactness with the RCC containing only natural aggregates. However, the compressive strength of the latter is higher due to the better quality of aggregates [24].

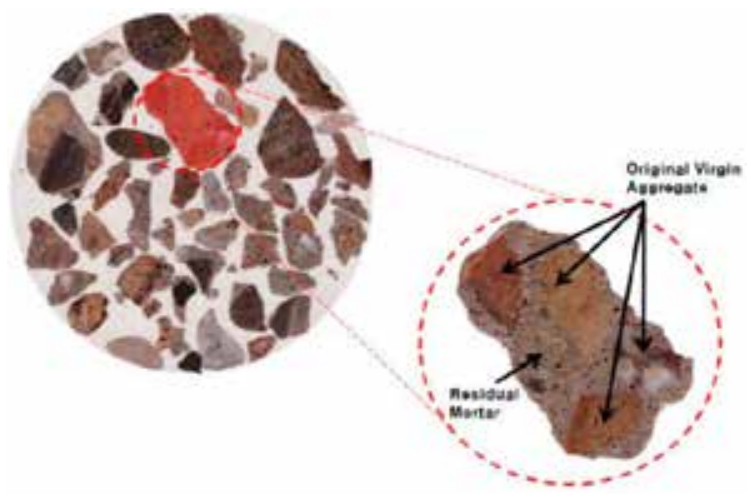

Figure 2 - Old Mortar/Residual Mortar in RCA [23]

The compactness of a material can be defined as the ratio between the volume of material and the total volume. However, efficient solid compactness is defined as the summation of solid compactness and absorbed water compactness. Solid compactness for both RCC made with RCA (RCA-RCC) and RCC made with virgin crushed aggregate (VCA-RCC) is in the same range. However, efficient solid compactness is quite different due to the higher water absorption coefficient of recycled aggregates.

In previous studies, it is observed that the compressive strength is higher in VCA-RCC than RCA-RCC in 28 days, mainly due to the better quality of aggregates. In contrast, water absorption is significantly high in RCA. Table 3 shows a comparison of compressive strengths and solid compactness of RCA-RCC and VCARCC. The recycled concrete aggregates used in the following study has a high water absorption value of $4.58 \%$ and has some parts of bitumen and clinker pavements which have led to a significant strength difference when compared to VCA-RCC [25].

Table 3 - RCA-RCC vs. VCA-RCC

\begin{tabular}{|c|c|c|}
\cline { 2 - 3 } \multicolumn{1}{c|}{} & RCA-RCC & VCA-RCC \\
\hline $\begin{array}{c}\text { Solid } \\
\text { compactness }\end{array}$ & 0.809 & 0.820 \\
\hline $\begin{array}{c}\text { Efficient solid } \\
\text { compactness }\end{array}$ & 0.864 & 0.820 \\
\hline $\begin{array}{c}\text { 7-day } \\
\text { compressive } \\
\text { strength }\end{array}$ & 23 & 41 \\
\hline $\begin{array}{c}\text { 28-day } \\
\text { compressive } \\
\text { strength }\end{array}$ & 28 & 46 \\
\hline
\end{tabular}




\section{Tests on Materials}

The materials used were tested for Aggregate Crushing Value (ACV), Aggregate Impact Value (AIV), Water absorption, and Specific gravity to assess their conformity with the specifications.

\subsection{Aggregate Crushing Value (ACV)}

$\mathrm{ACV}$ is a measure of the resistance of an aggregate sample to get crushed under a gradually applied compressive load. Virgin crushed aggregates in Sri Lankan quarries usually satisfy the specified ACV limits. However, ACV is tested for both RCA and VCA.

The average ACV obtained for the recycled aggregate test samples was 28 , and it is less than 30 , which is the specified maximum ACV for the aggregates used in pavement wearing surfaces.

\subsection{Aggregate Impact Value (AIV) Test}

AIV is a measure of the resistance of aggregates upon a sudden impact repetitively. AIV measures a different attribute from ACV. The percentage of particles that disintegrate upon sudden, repetitive impact is presented as a percentage in this test method.

The average AIV obtained for the recycled aggregate test samples was 21, and it is below 30 , which is the specified maximum AIV for the aggregates used for pavement wearing surfaces. Table 4 shows the range and mode of AIV and $\mathrm{ACV}$ test results obtained for virgin aggregates in Sri Lanka. According to the limits specified, manually crushed RCA can be used for pavement wearing surfaces, although it is not permissible to use for heavy-duty concrete finishes.

Table 4 - ACV and AIV Test Results Obtained by NBRO [26]

\begin{tabular}{|l|l|l|}
\hline $\begin{array}{l}\text { Statistics } \\
\text { of test } \\
\text { results }\end{array}$ & \multicolumn{2}{|c|}{ Aggregate Property } \\
\cline { 2 - 3 } Range & AIV & ACV \\
\hline Mode & 23 -41 & $17-41$ \\
\hline $\begin{array}{l}\text { Specified } \\
\text { maximum } \\
\text { limit }\end{array}$ & $\begin{array}{l}25 \text { for heavy- } \\
\text { duty concrete } \\
\text { finishes } \\
30 \text { for pavement } \\
\text { wearing } \\
\text { surfaces. } \\
45 \text { for others }\end{array}$ & $\begin{array}{l}30 \text { for pavete finishes } \\
\text { wearing surfaces. } \\
45 \text { for others }\end{array}$ \\
\hline
\end{tabular}

\subsection{Water Absorption and Specific Gravity} Test

Water absorption of coarse aggregates was tested for both recycled concrete aggregates and virgin crushed aggregates. Since fine aggregates were not replaced by recycled aggregates, water absorption and the specific gravity of sand were extracted from average test results obtained from the National Building Research Organization (NBRO). A summary of the results is included in Table 5. The typical range of values for the test results are given within brackets [26].

Table 5 - Water Absorption and Specific Gravity Test Results

\begin{tabular}{|c|c|c|}
\cline { 2 - 3 } \multicolumn{1}{c|}{} & $\begin{array}{c}\text { Specific } \\
\text { Gravity }\end{array}$ & $\begin{array}{c}\text { Water } \\
\text { Absorption }\end{array}$ \\
\hline RCA & 2.44 & $3.79 \%$ \\
\hline VCA & $\begin{array}{c}2.76 \\
(1.95-2.87)\end{array}$ & $\begin{array}{c}0.44 \% \\
(0.2-0.6)\end{array}$ \\
\hline $\begin{array}{c}\text { Fine } \\
\text { Aggregate }\end{array}$ & $\begin{array}{c}2.61 \\
(2.42-2.72)\end{array}$ & $\begin{array}{c}0.90 \% \\
(0.4-2.2)\end{array}$ \\
\hline
\end{tabular}

\section{Analysis of Results}

\subsection{Results of Compaction Tests}

In the optimum moisture content determination, compaction was carried out using the Modified Proctor Test (ASTM D1557) and Vibratory Hammer Test (BS1377: Part 4: 1990). In the proctor compaction test, the compaction is only due to an impact force. However, in vibratory hammer test impact compaction, a vibratory effect and a surcharge load are applied on compacting specimens.

The summary of all the compaction test results is summarized in Table 6.

Table 6 - Summary of OMC and Maximum Dry Density (MDD) Test Results

\begin{tabular}{|l|c|c|}
\cline { 2 - 3 } \multicolumn{1}{c|}{} & $\begin{array}{c}\text { Design } \\
\text { OMC }(\%)\end{array}$ & $\begin{array}{c}\text { MDD } \\
\left(\mathrm{kgm}^{-3}\right)\end{array}$ \\
\hline Proctor Test - VCA & 7.77 & 2305.50 \\
\hline Proctor Test - RCA & 12.04 & 2173.04 \\
\hline $\begin{array}{l}\text { Vibratory Hammer - } \\
\text { VCA }\end{array}$ & 6.56 & 2318.66 \\
\hline $\begin{array}{l}\text { Vibratory Hammer - } \\
\text { RCA }\end{array}$ & 11.67 & 2169.47 \\
\hline
\end{tabular}




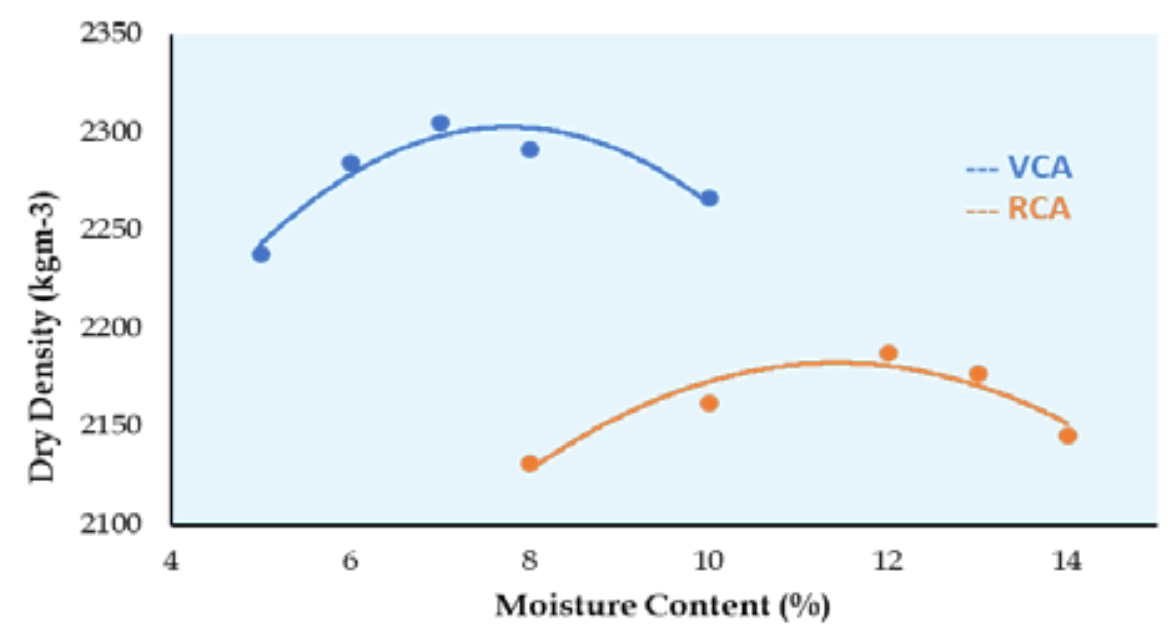

Figure 3 - VCA vs RCA (Modified Proctor Compaction Test)

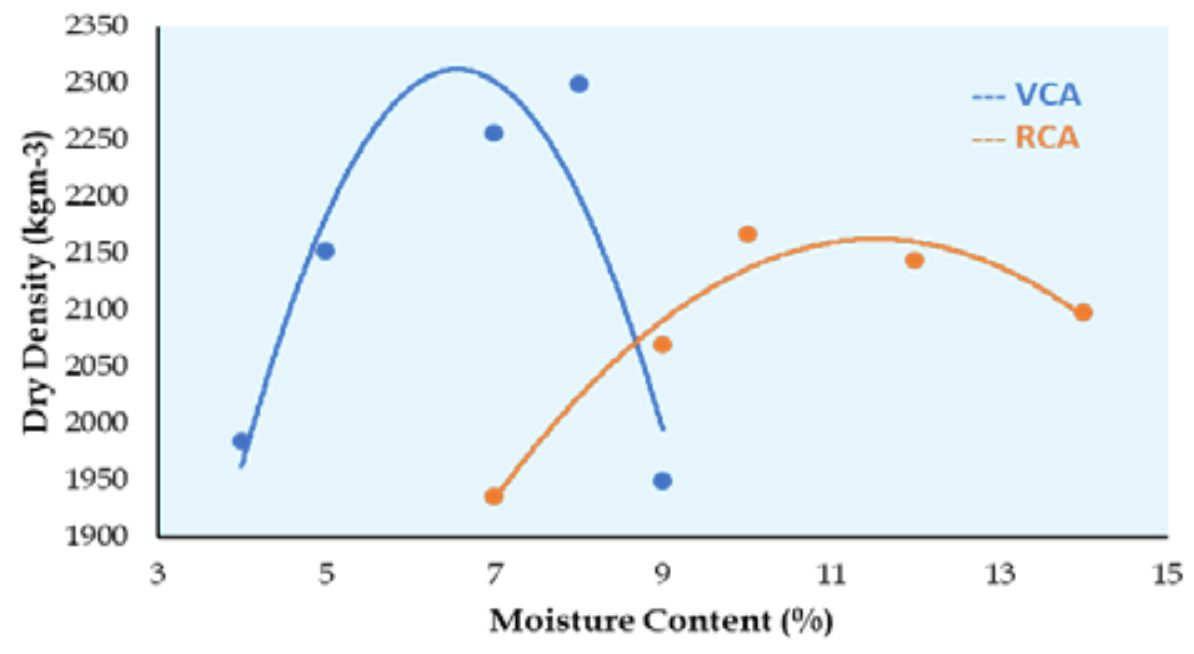

Figure 4 - VCA vs. RCA (Vibratory Hammer Test)

The dry density - moisture content relationship of RCC mixtures for the modified proctor compaction test method is shown in Figure 3. The design OMC observed by modified proctor test for RCA and VCA was $12.04 \%$ and $7.77 \%$, respectively. MDD of RCA and VCA were $2173.04 \mathrm{kgm}^{-3}$ and $2305.50 \mathrm{kgm}^{-3}$, respectively. VCA density is $6.1 \%$ higher than that of RCA.

Figure 4 shows the moisture content - dry density relationship of RCA and VCA aggregate, obtained using the vibratory hammer test method. Design OMC observed by Vibratory Hammer Test for RCA and VCA was $11.67 \%$ and $6.56 \%$, respectively.

Compaction test results of VCA-RCC samples are shown in Figure 5, and Figure 6 shows the compaction results of RCA-RCC. The two compaction methods are compared in each case. Both compaction methods resulted in an almost similar MDD value for VCA, but the moisture content at which it was achieved, was different.
For VCA-RCC, the vibratory hammer method requires only $6.56 \%$ moisture to reach the MDD, while the modified proctor test method requires $7.77 \%$.

For RCA-RCC, the vibratory hammer method requires only $11.67 \%$ moisture to reach the MDD, while the modified proctor test method requires $12.04 \%$.

MDD is considerably higher in VCA-RCC samples than RCA-RCC samples. The main reason is the quality of aggregates. Virgin aggregates have higher specific gravity than recycled aggregates. Therefore, the density of VCA-RCC samples was significantly higher than that of RCA-RCC.

Optimum moisture content (OMC) is considerably higher in RCA-RCC samples than VCA-RCC samples. The main reason is the higher water absorption of RCA. 


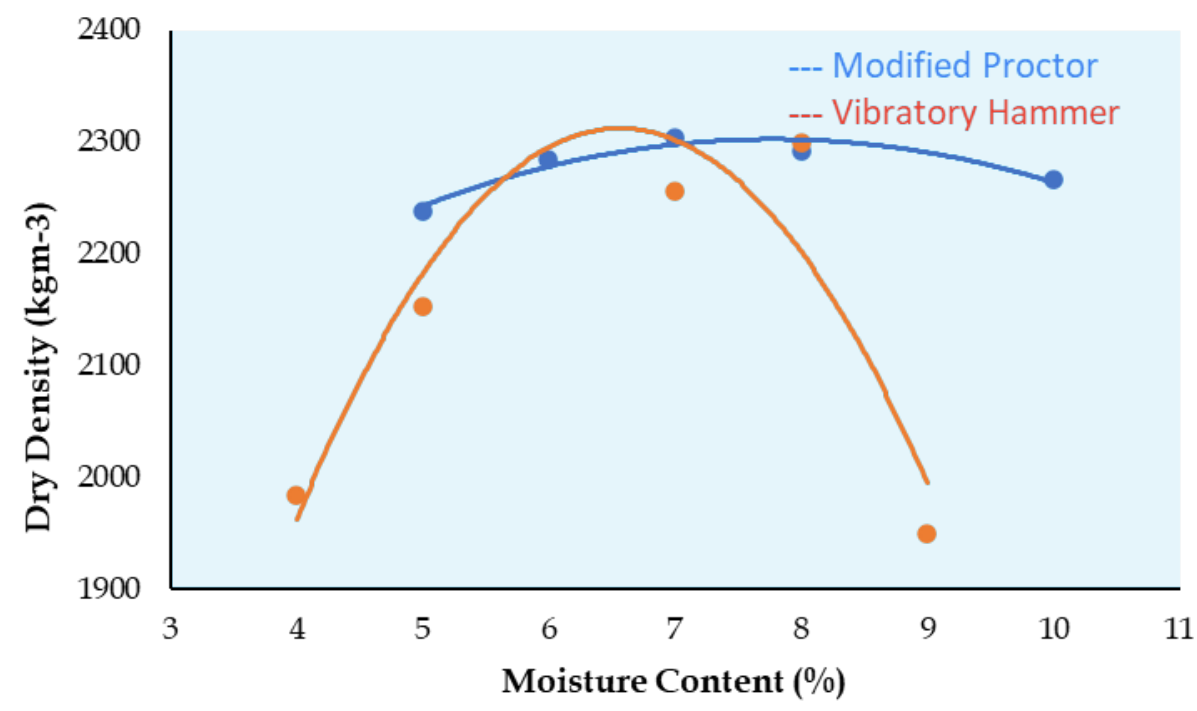

Figure 5 - Modified Proctor Test vs Vibratory Hammer Test for VCA

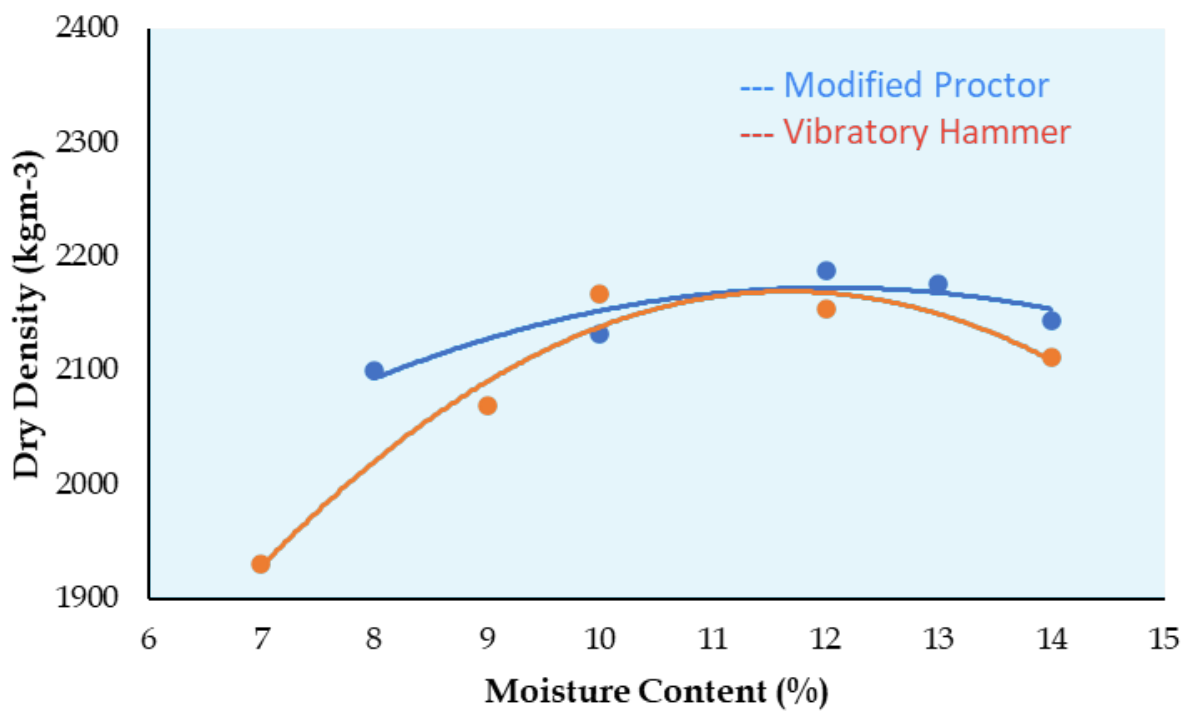

Figure 6 - Modified Proctor Test vs. Vibratory Hammer Test for RCA

When two compaction methodologies are compared, it clearly shows that both methods yield almost the same MDD but at different moisture levels. The vibratory hammer method requires low moisture for compaction, while Modified Proctor Compaction requires more moisture to reach MDD.

Figure 5 and Figure 6 show that the vibratory hammer method is very sensitive to moisture content than the modified proctor method. Even a little change in moisture content in the vibratory hammer test method can drastically decrease the dry density of the mix when compared with the modified proctor test method.

In compacting RCC at the site, steel drum rollers apply a surcharge, a vibration, and an impact force on dry RCC mix. Therefore, this scenario can be simulated using a vibratory hammer than the modified proctor test method. This shows the importance of maintaining correct OMC at the site and the importance of finding the optimum moisture content by the vibratory hammer test method.

\subsection{Results of Compressive Strength Tests of RCC Cylinders}

Six samples, each from RCA-RCC and VCARCC, were cured to check 7-day and 28-day compressive strength. VCA-RCC specimens were cast in parallel with RCA-RCC samples to be used as control samples of this experiment.

The 12 RCC cylinders were tested, and Figure 7 shows the graphical representation of test results. Values shown in Figure 7 are based on the average compressive strength of three RCC cylinder samples. 


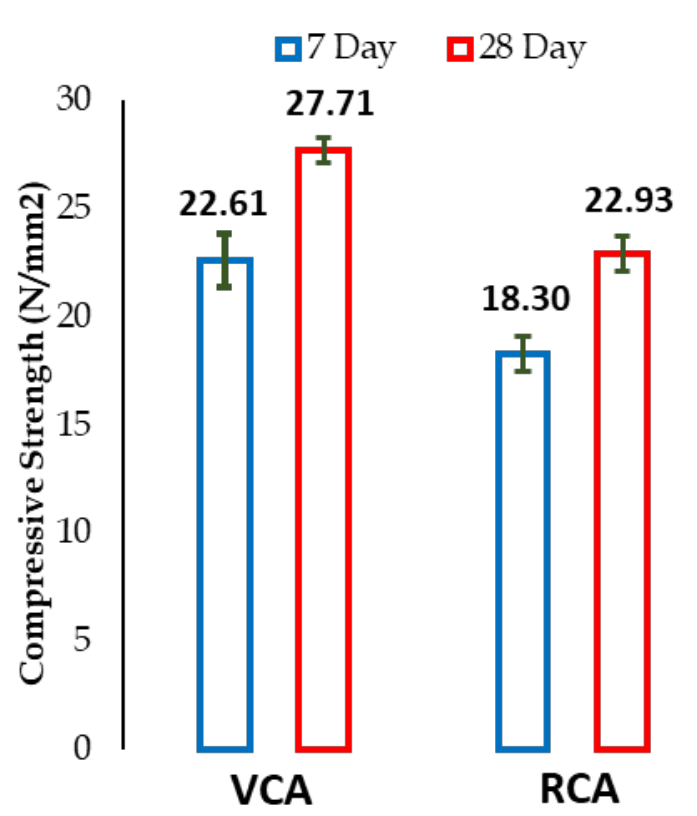

Figure 7 - Summary of Compressive Strength Results

The 28-day strength of all the samples was above 20MPa. RCA-RCC samples were below $25 \mathrm{MPa}$ in compressive strength, while all the control samples exceeded $25 \mathrm{MPa}$ in compressive strength.

Even though RCA-RCC has less strength than VCA-RCC, the standard error of strength results is not significant. Therefore, the consistency of compressive strength of samples is satisfactory.

VCA-RCC samples have increased $22.6 \%$ of their strength at 28-days relative to 7-day strength, while RCA-RCC samples have increased by $25.3 \%$. In RCA-RCC, the increment is higher than that of VCA-RCC.

Almost all the RCC cylinders showed the same failure pattern despite being VCA-RCC or RCARCC. As shown in Figure 8, the failure pattern was a combination of splitting and shear.

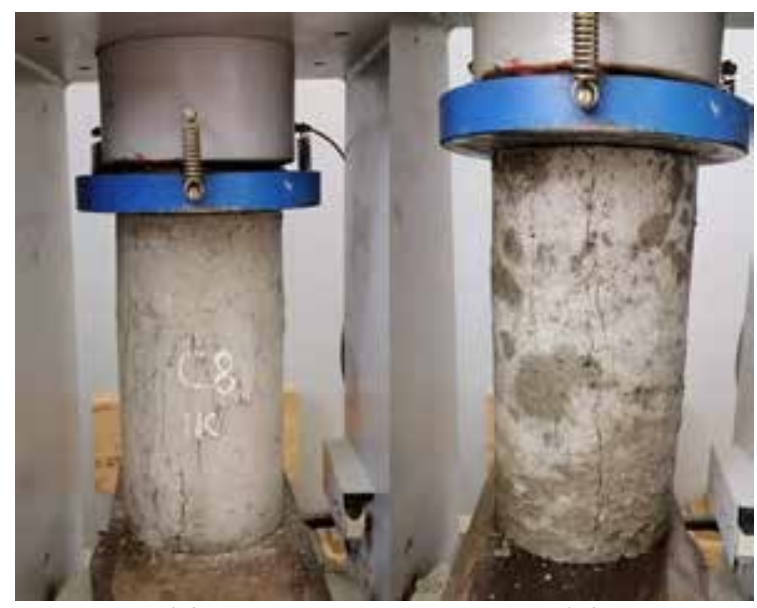

(a)

(b)

Figure 8 - Failure Pattern Observed (a) VCARCC, (b) RCA-RCC

\section{Conclusion}

It is possible to cast roller-compacted concrete using RCA. Therefore, instead of using deteriorated concrete pavements for landfilling or as a base layer for a new pavement, the entire pavement can be recycled and replaced with roller-compacted concrete with $100 \%$ replacement of coarse aggregates by recycled concrete aggregates. Even though a slight decrease in strength could be observed, it is good enough for traffic applications in a lowvolume road.

Summary of the research outcomes are listed out below:

- The dry density achieved by vibratory hammer compaction for the optimum moisture content obtained by the proctor compaction test is significantly lower than MDD. Therefore, for the determination of optimum moisture content for RCC, it is better to use the vibratory hammer method rather than using the modified proctor method since modified proctor compaction does not simulate the vibratory action of vibratory rollers.

- OMC vs MDD plot is more sensitive to the moisture content in the vibratory hammer test method than the modified proctor test method, which means actual site condition is more susceptible to moisture content than expected from the modified proctor test curve. Therefore, OMC should be appropriately maintained to achieve the desired MDD.

- Coarse aggregates used for RCC construction can be replaced by $100 \%$ with RCA without any significant fall of the compressive strength, provided that RCA with specified ACV and AIV are used. $20 \mathrm{MPa}$ of compressive strength can be attained from proper compaction of RCARCC at $12 \%$ cementitious material content.

\section{Acknowledgement}

The authors wish to acknowledge the support given by the Portland Cement Association (PCA), RCC Pavement Council, and The American Concrete Pavement Association (ACPA) for the valuable information provided for this study.

\section{References}

1. Road Development Authority, Sri Lanka, “National Road Master Plan (NRMP) 2018/2027 
- Final Draft," 2018. [Online]. Available: http://www.rda.gov.lk/supported/noticeboar d/publications/NRMP_2018-2027/NRMP20182027_Draft-final.pdf.

2. Rda.gov.lk. 2021. National Highways. [online] Available <http://www.rda.gov.lk/source/rda_roads.ht $\mathrm{m}>$ [Accessed 28 January 2021].

3. Mampearachchi, W. K., \& Priyantha, N. A. A. (2011). Development of Guidelines for Low Volume Concrete Road Construction in Sri Lanka.

4. ERMCO-Guide. Ermco Guide to Roller Compacted Concrete for Pavements. ERMCO, European Ready Mixed Concrete Organization; 2013

5. Harrington, D., Abdo, F., Adaska, W., Hazaree, C. V., Ceylan, H., \& Bektas, F. (2010). Guide for Roller-Compacted Concrete Pavements.

6. Jones, D., Harvey, J., Al-Qadi, I. L., \& Mateos, A (Eds.). (2012). Advances in pavement design through full-scale accelerated pavement testing. CRC Press.

7. N. Delatte, N. Amer, and C. Storey, "Improved Management of RCC Pavement Technology," 2003.

8. U.S. Army Corps of Engineers (USACE), “Roller Compacted Concrete Pavement Design and Construction," Washington, D. C., 1995.

9. Kalantari, B., Mafian, S., \& Huat, B. B. (2009). Rc Concrete Versus Conventional Concrete in Pavement. Contemporary Engineering Sciences, 2(1-4), 139-148.

10. Delatte, N., Amer, N., \& Storey, C. (2003). Improved Management of RCC Pavement Technology. UTCA Report, 1231, 54.

11. N. Mahasenan, S. Smith, and K. Humphreys, "The Cement Industry and Global Climate Change Current and Potential Future Cement Industry $\mathrm{CO}_{2}$ Emissions," in Greenhouse Gas Control Technologies - 6th International Conference, Elsevier, 2003, pp. 995-1000.

12. Mikulčić, H., Vujanović, M., Markovska, N., Filkoski, R. V., Ban, M., \& Duić, N. (2013). $\mathrm{CO}_{2}$ Emission Reduction in the Cement Industry. Chemical Engineering Transactions, 35, 703-708.

13. Sabnis, G. M. (Ed.). (2015). Green Building with Concrete: Sustainable Design and Construction. CRC Press.

14. Pittman, D. W., "Construction of RollerCompacted Concrete Pavements.," Transp. Res. Rec., pp. 13-19, 1986.
15. Brotman, I., Crist, M., and Gaul, J., "Roller Compacted Concrete Pavement: Properties, Design, and Construction," in Soil and Material Inputs for Mechanistic-Empirical Pavement Design, Oct. 2007, pp. 1-10, doi: 10.1061/40913(232)4.

16. Hazaree, C. V. (2007). Transport Properties and Freeze-Thaw Resistance of Roller Compacted Concrete (RCC) for Pavement Applications.

17. Choi, Y. K., \& Groom, J. L. (2001). RCC Mix Design-Soils Approach. Journal of Materials in Civil Engineering, 13(1), 71-76.

18. Amer, N., Storey, C., and Delatte, N., "RollerCompacted Concrete Mix Design Procedure with Gyratory Compactor," in Transportation Research Record, 2004, no. 1893, pp. 46-52, doi: 10.3141/1893-06.

19. Portland Cement Association. (2006). Production of Roller-Compacted Concrete. New York, USA, IS332.

20. ACI 211 Committee. (2002). Guide for Selecting Proportions for No-Slump Concrete Reported by ACI Committee 211. In American Concrete Institute (Vol. 2, pp. 1-26).

21. Duan, Z., Li, B., Xiao, J., and Guo, W., “Optimizing Mix Proportion of Recycled Aggregate Concrete by Readjusting the Aggregate Gradation," Struct. Concr., no. December 2019, pp. 1-11, 2020, doi: 10.1002/suco.201900517.

22. Kim, N., Kim, J., and Yang, S., "Mechanical Strength Properties of RCA Concrete Made by a Modified EMV Method," Sustain., vol. 8, no. 9, pp. 1-15, 2016, doi: 10.3390/su8090924.

23. Kim, J., "The Effect of Residual Mortar in Recycled Aggregate on Behavior of Recycled Aggregate Concrete," Korea University of Technology and Education, Cheonan, Korea, 2016.

24. Debieb, F., Courard, L., Kenai, S., and Degeimbre, R., "Roller Compacted Concrete with Contaminated Recycled Aggregates," Constr. Build. Mater., vol. 23, no. 11, pp. 33823387, Nov. 2009, doi: 10.1016/j.conbuildmat.2009.06.031.

25. Courard, L., Michel, F., and Delhez, P., "Use of Concrete Road Recycled Aggregates for Roller Compacted Concrete," Constr. Build. Mater., vol. 24, no. 3, pp. 390-395, 2010, doi: 10.1016/j.conbuildmat.2009.08.040.

26. Savitha, R., and Ranatunge, N. B. M., "A Study on Types and Quality of Aggregates Used in Building Construction," 2010. 